\title{
Battelfield Acupuncture and Femoral Nerve Block for Treatment of Postoperative Pain in Major Orthopedic surgery
}

\author{
Zrinka Orešković ${ }^{1}$, Sandra Morović ${ }^{\text {(D) }}$ \\ ${ }^{1}$ University Hospital Centre Zagreb, Zagreb, Croatia \\ ${ }^{2}$ Aviva Medical Center, Zagreb, Croatia
}

\section{ABSTRACT:}

INTRODUCTION: Postoperative pain after major orthopedic surgery is extremely severe and especially after revision surgery where bone destruction is extensive. The role of postoperative analgesia is very important. Opioid analgesics are commonly used for this purpose in continuous infusion in combination with the intravenous administration of paracetamol, metamizole and ketoprofen.

MATERIALS AND METHODES: The patient was admitted for revision surgery after a total hip endoprosthesis was installed. The patient is allergic to most analgesic medicines including fentanyl, alfentanyl, tramadol, buprenorphine, paracetamol, piroxicam, propifenazone, codeine, caffeine, diclofenac, ibuprofen. Only Ketoprofen and Oxycodonum are allowed analgesics.

OPEN ACCESS

Correspondence:

Zrinka Orešković MD zrinkaor@gmail.com orcid.orcid.org/0000-0002-1361-2124

This article was submitted to RAD CASA Medical Sciences as the review article

Conflict of Interest Statement: The authors declare that the research was conducted in the absence of any was conducted in the absence of any commerciat conflict of interest.

Received: 15 March 2020 Accepted: 24 June 2020 Published: 22 July 2020

Citation: Oreskovic $Z$ and Morović S. Battelfield acupuncture and femoral nerve block for treatment of postoperative pain in major orthopedic surgery RAD CASA - Medical Sciences. $543=50-51(2020): 63-66$ DOI: https://dx.doi.org/10.21857/ mnlqgc545y

Copyright (C) 2020 Oreskovic and Morović. This is an open-access article distributed under the terms of the reative Commons Attribution License

(CC BY). The use, distribution or reproduction in other forums is permitted, provided the original author(s) and the copyright owners(s) are credited and that the original publication in this journal is cited, in accordance

whit accepted adacemic practice. No

use, distribution or reproduction is permitted which does not comply with
In this case, postoperative analgesia was difficult because of the very narrow choice of analgesics. Researchers applied a regional femoral nerve block in combination with battlefield ear acupuncture, which has a pronounced analgosedative effect.

Pain was measured with an audio visual scale and allowed analgesics were added as needed

REsults: The patient was satisfied with achived analgesia and the side effects of analgesics were avoided. Conclusions: Battelfield ear acupuncture in combination with nerve block is a very effective method in the treatment of postoperative pain in major orthopedic surgery.

KEYWORDS: Major orthopedic surgery, Analgesia, Battelfield ear acupuncture, Nerve block

\section{SAŽETAK:}

AKUPUNKTURA BOLNOG POLJA I BLOKADA BEDRENOG ŽIVCA ZA LIJEČENJE POSTOPERATIVNE BOLI U VELIKOJ ORTOPEDSKOJ KIRURGIJI

UvoD: Postoperativna bol nakon velike ortopedske kirurgije izuzetno je jaka, posebno nakon revizijske operacije, gdje je uništavanje kostiju opsežno. Uloga postoperativne analgezije vrlo je važna. U tu se svrhu obično koriste opioidni analgetici u kontinuiranoj infuziji u kombinaciji s intravenskom primjenom paracetamola, metamizola i ketoprofena.

Materijali i metode: Pacijent je primljen na revizijsku operaciju nakon ugradnje totalne endoproteze kuka. Pacijent je alergičan na većinu analgetskih lijekova uključujući fentanil, alfentanil, tramadol, buprenorfin, paracetamol, piroksikam, propifenazon, kodein, kofein, diklofenak, ibuprofen. Samo su Ketoprofen i Oxycodonum dopušteni analgetici. U ovom je slučaju postoperativna analgezija bila teška zbog vrlo uskog izbora analgetika. Istraživači su primijenili regionalni bedreni bedreni živac u kombinaciji s akupunkturom uha na bojnom polju, koja ima izražen analgosedativni učinak. Bol se mjerila audiovizualnom skalom i dodavali dopušteni analgetici po potrebi Rezultati: Pacijent je bio zadovoljan postignutom analgezijom i izbjegnute su nuspojave analgetika. ZAKLJUČCr: Akupunktura uha Battelfield u kombinaciji s blokadom živaca vrlo je učinkovita metoda u liječenju postoperativne boli u velikim ortopedskim operacijama.

KLJUČNE RIJEČI: Velika ortopedska kirurgija, analgezija, akupunktura uha Battelfield, blok živca 


\section{INTRODUCTION}

After revision surgery of the total hip endoprosthesis, moderate to severe postoperative pain occurs due to severe bone destruction. It is very important to control postoperative pain becouse inadequate analgesia can delay adequate rehabilitation, prolong hospital stay and increase treatment costs ${ }^{1,2,3}$.

Opioid analgesics are commonly used in the treatment of postoperative pain, which is known to have a large number of side effects. They are often combined with other analgesics (paracetamol, methamizole, NSAIDs) which also have numerous side effects. Therefore, it is necessary to determine the optimal dose that will suppress the pain while causing as few side effects as possible $e^{4,5,6}$.

The National Institutes of health and the World Health Organisation approved acupuncture as a safe and effective method of treating pain ${ }^{7,8}$.

Inserting needles into acupuncture points releases endorphins, enkephalins and dynorphins, which are important substances in the mechanisms of analgesia. Many studies prove this ${ }^{9,10,11}$. Analgesic sedation protocol Battlefield ear acupuncture is used to treat many pain conditions. Author Niemtzow start to use it in 2001. Needles are inserted on ear five specific spots. It cause changes the processing of pain in the central nervous system. Release of beta-endorphins allows short-term analgesia and release of anti-inflammatory cytokines allows long-term analgesic effects. This therapy reduces headaches, neuropathic pain and musculoskeletal pain ${ }^{12,13}$.

Meta-Analysis and systematic rewiew analised Battlefield ear acupuncture studies. Pain scores were significantly reduced, there were no significant side effect and patients were satisfied ${ }^{14}$. Femoral 3-in-1 nerve block discontinue sensation and motor power in 3 nerve distributions (femoral nerve, lateral femoral cutaneous neve, obturator nerve). It is usefull for treatement of postoperative pain on hip area.

Regional nerve blocks have a benefit in reducing pain after procedures on hip area and significantly reduce need for opioides. ${ }^{15}$

\section{MATERIALS AND METHODES}

The participant was admitted to the department of orthopedics for revision surgery after the total hip endoprosthesis was installed. The participant was allergic to most analgesic drugs including fentanyl, alfentanyl, tramadol, buprenorphine, paracetamol, piroxicam, propifenazone, codeine, caffeine, diclofenac, ibuprofen. Only Ketoprofen and Oxycodonum were allowed analgesics. Spinal anesthesia was performed for surgery. Pain was postoperatively measured by a visual analogue scale (VAS) in which 0 indicates the pain-free status and 10 the strongest pain possible. Analgesia was determined based on the VAS scale. Postoperative analgesia was difficult to performe because of the narrower choice of analgesics. The ivestigators first choice was 3 in 1 femoral nerve regional block in combination with Battlefield ear acupuncture that has a strong analgo sedative effect.
Femoral block 3 in 1 was performed with ultrasound control, $10 \mathrm{ml}$ of $2 \%$ Lidocain and $10 \mathrm{ml}$ of $0.5 \%$ Levobupivacaine were administered around the nerve. Battelfield ear acupuncture was performed with disposable sterile needles that were placed at five points of the ear (Omega2, ShenMen, Zero point, Thalamus, and Gyrus cinguli) on both ears and left for 30 minutes and then removed.

During the $24 \mathrm{~h}$ postoperative period, the patient additionaly received Ketoprofen 2 x $100 \mathrm{mg}$ iv and Oxycodon $20 \mathrm{mg}$ iv for analgesia. The strongest pain was recorded after spinal anesthesia was weaken and just before the application of nerve block and acupuncture, and the VAS scale was 8 and 9. Thereafter, the pain gradually decreased to VAS 5 and 4 and overnight to 3 and 2.

\section{RESULTS}

The participant was very satisfied with achived analgesia. The use of a large amount of analgesics was avoided and also a number of potential side effects. Conclusion is that the combination of nerve block and Battelfield acupuncture is very effective in treating pain after extensive orthopedic surgery.

\section{DISCUSSION}

Battelfield ear acupuncture was developed by Niemtzow who investigated a model of ear acupuncture for effective analgesia. Battelfield ear acupuncture provides a significant analgesic effect in a very short period after administration ${ }^{16}$.

MRI studies suggest that hypothalamus, thalamus, gyrus cingu$\mathrm{li}$, and cerebral cortex are involved in the modulation of pain in the central nervous system by the Battlefield method ${ }^{17}$.

The analgesic effect of acupuncture has been proved in many controlled clinical trials on large samples of participants. This effect is mainly caused by increased release of endorphins (endogenous opioid neuropeptides ${ }^{18}$.

Acupuncture causes an increase in beta-endorphin levels from the pituitary-hypothalamic region in the cerebrospinal fluid. The use of opiate antagonists abolishes analgesia achieved by acupuncture $^{19}$.

Acupuncture affects the sympathetic system and the opioid receptors of the spinal cord ${ }^{20}$.

Very fast, effective and long-lasting analgesia is achieved by femoral nerve block 3 in 1 for severe pain in the hip area. The method is very simple and safe ${ }^{21}$. 


\section{LITERATURE :}

1. Halawi MJ, Grant SA, Bolognesi MP.:Multimodal analgesia for total joint arthroplasty. Orthopedics 2015; 38: 616-625.

2. Dahl JL, Gordon D, Ward S, Skemp M, Wochos S, Schurr M.: Institutionalizing pain management: the post-operative pain management quality improvement project. J Pain 2003;4:361-371.

3. Apfelbaum JL, Chen C, Mehta SS, Gan TJ.: Postoperative pain experience: results from a national survey suggest postoperative pain continues to be undermanaged. Anesth Analg. 2003;97:534-540. 4. Sinatra RS, Jahr JS, Reynolds LW, Viscusi ER, Groudine SB, Payen-Champenois C.: Efficacy and safety of single and repeated administration of 1 gram intravenous acetaminophen injection (paracetamol) for pain management after major orthopedic surgery. Anesthesiology. 2005;102 (4):822-831

5. Hernandez-Palazon J, Tortosa JA, Martinez-Lage JF, Perez-Flores D.: Intravenous administration of propacetamol reduces morphine consumption after spinal fusion surgery. Anesth Analg. 2001; 92 (6):14731476

6. Peduto VA, Ballabio M, Stefanini S.: Efficacy of propacetamol in the treatment of postoperative pain. Morphine-sparing effect in orthopedic surgery. Italian Collaborative Group on Propacetamol. Acta Anaesthesiol Scand. 1998; 42 (3):293-298

7. NIH Consensus Conference. Acupuncture. JAMA. 1998 Nov 4:280(17):1518-24

8. Viewpoint on Acupuncture. Geneva, Switzerland; World Health Organisation, 1979

9. Tsuei JJ.: Recent developments in clinical acupuncture. Am J Chin Med. 1983;11(1-4):150-8.

10. Ho WK1, Wen HL.: Opioid-like activity in the cerebrospinal fluid of pain patients treated by electroacupuncture. Neuropharmacology. 1989 Sep;28(9):961-6.

11. He LF, Dong WQ.: Activity of opioid peptidergic system in acupuncture analgesia. Acupunct Electrother Res. 1983;8(3-4):257-66.
12. Goertz CM1, Niemtzow R, Burns SM, Fritts MJ, Crawford CC, Jonas WB.: Auricular acupuncture in the treatment of acute pain syndromes: A pilot study. Mil Med. 2006 Oct;171(10):1010-4.

13. Plunkett A1, Turabi A, Wilkinson I.: Battlefield analgesia: a brief review of current trends and concepts in the treatment of pain in USmilitary casualties from the conflicts in Iraq and Afghanistan. Pain Manag. 2012 May;2(3):231-8.

14. Jan AL1, Aldridge ES1, Rogers IR1,2, Visser EJ3, Bulsara MK4, Niemtzow RC5.: Does Ear Acupuncture Have a Role for Pain Relief in the Emergency Setting? A Systematic Review and Meta-Analysis. Med Acupunct. 2017 Oct 1;29(5):276-289.

15. Ritcey B, et al. : Regional Nerve Blocks For Hip and Femoral Neck Fractures in the Emergency Department: A Systematic Review. CJEM 2016 - Review. PMID 26330019

16. Niemtzow RC. Battlefield acupuncture. Med. Acupunct. 2007;19: 225-8

17. Cho ZH, Wong EK and Fallon J, Neuro-Acupuncture, Los Angeles, USA; Q-puncture, inc, 2001.

18. Hökfelt T1. The new neuroendocrinology-a perspective. 2018 Dec;284(6):563-567.

19. Sjölund B, Terenius L, Eriksson M. Increased cerebrospinal fluid levels of endorphins after electro-acupuncture. Acta Physiol Scand. 1977 Jul;100(3):382-4.

20. Knardahl S1, Elam M, Olausson B, Wallin BG. Sympathetic nerve activity after acupuncture in humans. Sympathetic nerve activity after acupuncture in humans. Pain. 1998 Mar;75(1):19-25.

21. Somvanshi M, et al. Femoral nerve block for acute pain relief in fracture shaft femur in an emergency ward. Saudi J Anaesth. Oct-Dec 2015; 9 (4), 439-41. 
Review Article 